\title{
ÁROPTIMALIZÁLÁS
}

\section{ÖKONOMETRIAI MODELLEZÉSEN ÉS AZ EMPIRIKUS KERESLETI FÜGGVÉNY MEGHATÁROZÁSÁN ALAPULÓ ÁRAZÁSI TECHNIKÁK}

Egy termék vagy szolgáltatás optimális beárazásának fontossága magától értetôdô, ennek ellenére szinte közhelyszerú megállapítás az idevágó szakirodalomban, hogy a vállalatok jó része nem fordít a téma fontosságának megfeleló figyelmet (Cram, 2006; Dolan - Simon, 2000; Monroe 1990). Az árképzési technikák egy csoportja a keresletalapú árképzés, amelyen belül a kinyilvánított vásárlási hajlandóság vizsgálatának két új lehetôségét mutatja be a tanulmány. A kidolgozott módszerek lényege a piackutatási adatgyuújtés során kinyilvánított vásárlási hajlandóság alapján meghatározott keresleti görbe és árrugalmassági együttható vizsgálata, amely elvezet az árbevétel maximalizálása melletti optimumárhoz. Ezt az optimum ár-meghatározási algoritmust alkalmazza a szerzó egy többváltozós binomiális logisztikus regresszió modellre, és egy viszonylag egyszerú, a kinyilvánított keresleti függvény és az árrugalmassági együttható pontos meghatározásán alapuló módszerre.

Kulcsszavak: ármeghatározás, optimumár, mikroökonometria, árrugalmassági együttható, keresleti függvény

A vállalatvezetók óvatossága és bizalmatlansága a keresletalapú árképzési módszerekkel szemben annak is tulajdonítható, hogy viszonylag kevés módszer áll rendelkezésünkre, és ezek között mindmáig olyanok is vannak a gyakorlatban, amelyek erősen megkérdőjelezhetô eredményt nyújtanak. A tanulmány célja a marketingkutatási ártesztek módszertanának fejlesztése, elsősorban ökonometriai modellek adaptálásával, de a keresleti függvény és az árrugalmassági együttható empirikus meghatározására alkalmazható gyakorlati technikát is bemutatok.

\section{Mikroökonometriai modellek}

A többváltozós gazdaságstatisztika és az üzleti tudományok határterületén egy új diszciplína alakult ki, aminek a kilencvenes évektól egyre közismertebb neve a mikroökonometria. Hausman (2001) meghatározása szerint a nemzetgazdasági folyamatok ökonometriai modellezése helyett a mikroökonómiai egységek: a fogyasztó, a háztartás és a vállalat piaci viselkedésére vonatkozó adatok elemzésére irányul. A téma aktualitását és súlyát jelzi, hogy a 2000. évi közgazdasági
Nobel-díjat a téma két úttörő fejlesztőjének, James J. Heckman és Daniel McFaddennek ítélték. Munkásságuk nagyrészt a nemlineáris regresszió modellek egy családjára, a kategoriális és korlátozott eredményváltozójú (Categorical and Limited Dependent Variables $C L D V)$ modellekre irányult. McFadden Nobel-díjat éró érdemének a kvalitatív döntési modellek (Qualitative Choice Models) mérési problémájának egy általános, és a közgazdasági döntéselmélethez kapcsolódó megoldását tartják (Kézdi, 2005). Konkrétabban fogalmazva a döntési modellek és a regresszió modellek, azon belül a logisztikus regresszió modellek összekapcsolásáról beszélhetünk. A gazdaság- és társadalomtudományi empirikus kutatások során nagyon sok olyan szituációt szükséges elemezni, amelyben a modellezni kívánt jelenség inkább diszkrét, mint folytonos változóval jellemezhető. E modellek közös jellemzóje a magyarázott, függő változó diszkrét, kategoriális jellege, ezért a lineáris regresszió modellek nem, vagy csak részlegesen alkalmazhatók. Röviden összefoglalva a $C L D V$ modellek közös jellemzőit, illetve előnyeit a lineáris regresszió modellel szemben: 
- nem tételezik fel a függó és a független változók közötti lineáris kapcsolatot,

- a paraméterek becslési módja nem a legkisebb négyzetek módszere, hanem leggyakoribb a maximum likelihood becslési eljárás, de más módszerek is alkalmazhatók,

- a függố változó kétértékú kategoriális (dichotóm) változó, és a független változók bármilyen típusúak lehetnek: intervallum, ordinális, nominális. Ez a „technikai előny” empirikus kutatásokban és különböző alkalmazásokban igen nagy jelentôségú. ${ }^{1}$

Ezek a modellek egyre nagyobb teret hódítanak a szakirodalomban és a gyakorlatban. Több ökonometriai kézikönyv legalább egy fejezetet szán a témának (Creel, 2002; Davidson - MacKinnon, 1999; Greene, 2003; Koop, 2003; LeSage, 1999), és a gyakorlati alkalmazások, adaptációk széles spektruma jelent meg. Marketingkutatási területen is sokféle céllal használhatók a CLDV, ezen belül a logisztikus regresszió modellek: a keresleti oldal szegmentációja, elégedettségvizsgálatok során, a tanulmány fő témája egy specifikus alkalmazás: egy termék/szolgáltatás keresletének a vizsgálata és az optimális ár meghatározása.

\section{Árképzés a gyakorlatban}

Az optimális árképzést többen a marketing egyik legfontosabb kérdésének tekintik (Gijsbrechts, 1993; Monroe, 1990). Monroe (1990: p. 18.) szerint azoknak a vállalatoknak van sikeres árképzési gyakorlata, amelyek tudatosan törekednek az árral kapcsolatos döntéseik fogyasztói reakcióinak folyamatos vizsgálatára, annak megértésére, hogy hogyan érzékelik a fogyasztók az árat, és hogyan alakítják az érték percepcióját. Az árképzési módszerek három nagy csoportja (Bauer - Berács, 2002: p. 259.) az ár viszonyítási alapja szerint különül el:

1. Költségelvű vagy haszonkulcsos árképzés. Az árnak fedezetet kell nyújtania a költségekre és egy elôre megállapított nyereségre. Olyan piacon, ahol a vállalat nem tudja befolyásolni a piaci árat, alapvetô kérdés, hogy a vállalat rendelkezik-e akkora termelési kapacitással, amely meghaladja a fix és változó költségek által meghatározott fedezeti pontot.

2. Versenytársakhoz igazodó árképzés. A piaci árakat a kereslet és kínálat egyuitt határozza meg. Ha egy vállalat új termékkel jelenik meg a piacon, akkor elsősorban nem a kereslet alapján tájékozódik, hanem megvizsgálja a hasonló termékek versenytársak által alkalmazott árait, és aszerint alakítja ki a sajátját.
3. A keresletelvú árképzés egyik meghatározó szempontja, hogy a termék milyen életgörbeszakaszban található. Kétféle alaptípusa közül a behatolásos stratégia olyan alacsony árat határoz meg, amely a versenytársak árai alatt van, ezáltal a piaci részesedés növelésével kecsegtet. Ez jellegében inkább az előző két árképzési módszer kombinációjának tekinthető, míg a másik módszertani véglet a lefölözési stratégia, a kereslet fogyasztói többletére irányul, és célja a minél nagyobb extraprofit elérése. A tanulmányban bemutatott két ármeghatározási módszer ez utóbbi csoportba sorolható, de nemcsak a termékéletciklus telítődési szakaszában alkalmazhatók, hanem elsősorban a bevezetésnél. Alkalmazásaiknak alapvető feltétele, hogy viszonylag tág terjedelem legyen a költségek által meghatározott fedezeti pont és a piaci ár között - ha nem teljesen új termékról van szó. Ez a feltétel adódhat egy természetes vagy mesterséges monopólium, termékinnovációnak köszönhető versenyelőny, erôs márkaismertség és lojalitás kvázi monopóliuma, vagy akár egy gyártási technológia fejlesztésének köszönhetô költségcsökkenés esetén.

Tóth István János és Vincze János (1998) a magyarországi kis-, közép- és nagyvállalatok árképzési gyakorlatának vizsgálata alapján megállapítja, hogy az inputárak változása a legfontosabb, a kereslet hatása sokkal kevésbé, és a technológia szerepe az árazásban nem nagyon lényeges. Egy új termék ármeghatározásánál figyelembe vett tényezók közül a fajlagos termelési költségek és a minőség megtartásának szükségességét követik a piaci keresleti feltételek és a tradicionális versenytársak árai. Megállapítható, hogy a magyar vállalatok körében a költségelvû és a versenytársakhoz igazodó módszerek mellett a keresletalapú árképzés is megjelenik.

A keresletalapú árképzés alapját a piaci kereslet felmérése jelenti. Alapvető kérdés, hogy a piackutatás mire irányuljon, a potenciális fogyasztók mi alapján mondanak árat? A belsố referenciaár Rekettye (1999: p. 52.) szerint az az érték, amit a fogyasztó egy adott áruért indokoltnak tart megadni. Ennek mértékét leginkább a jelenlegi árak, a múltbéli árak és a vásárlási szituáció befolyásolja. A referenciaár megismerésére több árkutatási módszert fejlesztettek ki a piackutatásban.

\section{Árkutatási módszerek}

Cram (2006: p. 25.) szerint is meglepóen kevés cég alkalmazza megfelelően és hatékonyan az árkutatási módszereket. Idézi Monroe és Cox (2001) kutatását, 
akik azt találták, hogy a vizsgált cégek $88 \%$-a egyáltalán nem, vagy csak kismértékben veszi komolyan a keresleti oldal vizsgálatán alapuló árkutatásokat. Ennek egyik nyomós oka a módszertani bizonytalanságok mellett az lehet, hogy fenntartásokkal kezelik a kinyilvánított vásárlási hajlandóságon alapuló információt, az angol szakirodalmi rövidítés szerint a WTP-t (willingness to pay). Azonban az adatbázis-technológiák, a keresletre vonatkozó információk on-line és real time megszerzésének lehetôsége, a marketinginformációs rendszerek fejlődése nemcsak az adatok minőségét és megbízhatóságát, hanem az alkalmazható módszerek spektrumát is bôvítette. Cram (2006: p. 26.) a következó két csoportba osztva sorolja fel az árkutatási módszereket:

határozására irányuló, az árbevétel maximalizálását célul túző módszer.

Az indirekt módszerek az ár mellett más termékjellemzôket is figyelembe véve az egész csomagra vonatkozóan tesznek fel kérdéseket, és ebból következtetnek az árra. Ilyenek például a Conjoint-modellek különbözô fajtái, a diszkrét választási modellek (Discrete Choice Models), és ide sorolhatók az ökonometriai modellek is.

A rezervációs árra vonatkozó kérdés direkt vagy indirekt jellege szerinti csoportosítás mellett érdemes figyelembe venni, hogy az elemzés során csak az ár vagy más tényezók keresletre gyakorolt hatását vizsgáljuk-e. Eszerint megkülönböztetünk egy- és többdimenziós módszereket.

\section{1. táblázat}

Árkutatási módszerek tipológiája

\begin{tabular}{|l|c|c|}
\hline & Egydimenziós módszerek & Többdimenziós módszerek \\
\hline $\begin{array}{l}\text { Kinyilvánított } \\
\text { kereslet }\end{array}$ & Közvetlen megkérdezés nyitott kérdéssel & $\begin{array}{c}\text { Conjoint-modellek } \\
\text { Gabor - Granger } \\
\text { Van Westendorp } \\
\text { Tényleges } \\
\text { kereslet }\end{array}$ \\
\hline
\end{tabular}

Forrás: saját szerkesztés

1. A vásárlási hajlandóság vizsgálatán alapuló módszerek: közvetlen megkérdezés nyitott kérdéssel, a Gabor-Granger-módszer, a Van Westendorpmodell (PSM), a Conjoint-elemzések különböző formái és a diszkrét választási modellek (Discrete Choice Models).

2. A tényleges vásárlási adatokon alapuló módszerek. A különböző értékesítési adatforrások mellett ide sorolhatók a szimulált vásárlási tesztek, áruházi kísérletek is, amelyek lényegesen jobban mérik a rezervációs árat, mint az előbbi csoportba tartozó piackutatási módszerek, mivel a vásárlási szituáció tényleges marketingmix-feltételek közé van helyezve (Wertenbroch - Skiera, 2002). Pritchard (2009) cikkében további két csoportba bontja a vásárlási hajlandóság vizsgálatán alapuló módszereket:

A direkt árkutatási technikák alapvetô premisszája, hogy a célpiacba tartozó interjúalanyok tudják, hogy számukra a vizsgált termék/szolgáltatás mennyit ér, és ezért értelmezni tudják a közvetlenül az árra vonatkozó kérdést. Ide tartoznak a Gabor-Granger-modell, a BPTO, a Van Westendorp-modell és a késóbbiekben bemutatásra kerüló, a keresleti függvény pontos meg-
A tanulmány keretein belül nincs lehetóség az árkutatási módszerek részletes bemutatására és kritikai elemzésére. Az 1. táblázatban feltüntetettek mellett sokféle saját fejlesztésú módszer, „márkázott termék” is megjelenik a nagyobb cégek kínálatában, de rövid leírásaikból általában nem visszafejthetô, hogy valamelyik ismert módszer adaptációjáról, vagy egy teljesen új megközelítésról van-e szó. Az elmúlt egy-két évtized legelterjedtebb és legalaposabb szakirodalmi feldolgozottsággal rendelkezó árkutatási módszere a Conjoint-modellcsalád, Srinivasan évi tízezerre becsüli az alkalmazások számát (Martin, 2009). Népszerúségének egyik oka, hogy nemcsak a vizsgált termék jellemzőit mutatják be a kutatás során, hanem akár a versenytárs termékek jellemzőit is, ezzel sokkal inkább leképezve a valós piaci, vásárlási szituációt.

Elmondható erról a módszerról, hogy nem csak az árkutatásra fejlesztették ki, az ár egy a többi ismérv közül. Ennek tulajdonítható, hogy a legtöbb kutatási eredményben nagyon hátrasorolódik az ár fontossága a valóságosnál alacsonyabb árrugalmasságot, következésképp magasabb árat eredményezve (Lyon, 2002)². A diszkrét választási modellt (Discrete Choice Model) Choice-Based Conjoint-nak is nevezik, amelyet nemlineáris ökonometriai - leggyakrabban a multinomiális 
logit - modellen alapuló Conjoint-megoldásnak tekinthetünk, és ma már ez, vagy valamilyen rá épülő márkázott termék jelenti a piackutató cégek árkutatási módszereinek a csúcsát. Jellemzố trendként megállapítható, hogy az egyszerúbb módszerek (például a Van Westendorp-módszer) el fognak tûnni a marketingkutatási gyakorlatból, a Choice-Based Conjoint és más ökonometriai modell alapú termékek pedig egyre népszerúbbé vállnak.

Ezt a térhódítást az egyre jobban adaptálható és felhasználóbarát márkázott termékek kifejlesztése és a piackutatók ökonometriai képzettségének a növekedése indukálja. A hagyományos, lineáris modellen alapuló Conjoint-megoldások is ki fognak kopni a ChoiceBased Conjoint és az ökonometriai modellek mellől, ugyanis semmivel sem egyszerúbb az adatfelvételük a lényegesen rosszabb eredménnyel szemben. A jövőben pedig a vásárlási szituációt minél jobban imitáló, jó minôségú adatfelvétel szúkebb keresztmetszet lesz, mint az ökonometriai képzettséggel rendelkező piackutató. E komplexebb modellek mellett valószínúleg megmaradhatnak az árban és gyorsaságban sokkal versenyképesebb legegyszerúbb módszerek, mint például a nyitott kérdésen alapuló, vagy a különböző, a vásárlási szituációt jobban imitáló kísérletek. A rövid áttekintés alapján is belátható, hogy a keresletalapú, kinyilvánított vásárlási hajlandóságon alapuló árképzési módszerek fenti listájának bóvítése nem időszerútlen vagy öncélú próbálkozás.

\section{A binomiális logisztikus regresszió modellen alapuló árkutatási módszer}

Az ökonometriai, szúkebb értelemben véve a binomiális logisztikus regresszió modellen alapuló árkutatási módszer optimalizálási szempontja és kiindulópontja az az összefüggés, miszerint egy termék értékesítéséból származó árbevétel ott éri el a maximumpontját, ahol az árrugalmassági együttható egyenlő mínusz eggyel. Noha a mikroökonómiai tankönyvek általában megfogalmazzák és tárgyalják ezt az állítást, empirikus kutatásokban nem találkoztam gyakorlati alkalmazásával. Varian (1990: p. 342-344.) háromféleképp is vizsgálja azt az egyenlőtlenséget, hogy mikor lesz a csökkenó ár-növekvő mennyiség (vagy fordítva) hatások eredője pozitív. Az egyik megközelítés analógiájára levezetem ezt az állítást, mivel a kifejlesztett módszer szempontjából kritikus fontosságú.

Az árbevételi függvény maximumpontját keressük, azaz:

$$
T R=p \cdot q(p) \rightarrow \max
$$

ahol $p$ az ár és $q(p)$ az eladott mennyiség az ár függvényében, vagyis a keresleti függvény. A maximumpontot ott találjuk, ahol az ár szerinti elsôrendú derivált egyenlő nullával. ${ }^{3}$

$$
\begin{aligned}
& \frac{d T R}{d p}=\frac{d(p \cdot q(p))}{d p}=q(p)+p \cdot \frac{d q(p)}{d p}=0 \\
& \frac{d q(p)}{d p}=-\frac{q(p)}{p}
\end{aligned}
$$

Ebból kifejezve az árrugalmassági együttható képletét, igazoljuk az állítást:

$$
\varepsilon_{\mathrm{p}}=\frac{d q(p)}{d p} \cdot \frac{p}{q(p)}=-1
$$

A módszer kiinduló alapösszefüggését tehát ez az árrugalmassági együttható és a maximális árbevétel közötti összefüggés jelenti. A binomiális logisztikus regresszió modell alkalmazása esetén a keresleti függvényt jelentő logisztikus regresszió egyenlet:

$$
Q=y=\frac{e^{(\beta x+\gamma z)}}{1+e^{(\beta x+\gamma z)}},
$$

ahol az $x$ független változó az árat jelenti, a $z$ a többi független változó vektora. Az optimumárhoz tartozó paramétert $b$-vel jelölve a következóképp írhatjuk fel az árrugalmassági együttható képletét:

$$
\begin{aligned}
& \varepsilon_{\mathrm{p}}=\frac{\delta \mathrm{Q}}{\delta \mathrm{p}} \cdot \frac{\mathrm{p}}{\mathrm{Q}}=\frac{b \cdot e^{y}}{\left(1+e^{y}\right)^{2}} \cdot \frac{x \cdot\left(1+e^{y}\right)}{e^{y}}= \\
& \frac{b \cdot x}{e^{y}}=b \cdot x \cdot(1-y)
\end{aligned}
$$

Az $\varepsilon_{\mathrm{p}}=-1$ összefüggésból könnyen kifejezhetô az optımálıs árat jelentô $x$ érték, ezúttal már a vásárlás becsült valószínúségét a kinyilvánított vásárlási hajlandóságtól való megkülönböztetés kedvéért $y^{*}$-gal jelölve:

$$
p_{o}=x=\frac{1}{b \cdot\left(\mathrm{y}^{*}-1\right)}
$$

A képlet alapján tehát az optimális ár értéke függ az ár $b$ paraméterétôl és a vásárlás becsült valószínúségétôl, az $y^{*}$-tól, vagyis esetról esetre változik, ahogy a magyarázó változók különböző rögzített értéket vesznek fel. 


\section{A binomiális logisztikus regresszió modellen alapuló árkutatási módszer empirikus próbája}

Az optimumár meghatározásának módszertanát egy 2003-as piackutatási projekt adatain keresztül mutatom be, amely egy új mobil telekommunikációs szolgáltatáscsomag keresletének felmérésére irányult. A kutatás fố célja az új tarifacsomag beárazása, az árbevétel maximalizálása melletti optimális ár meghatározása volt. E célnak volt alárendelve a kérdezés technikája is, az akkor még Magyarországon újdonságnak számító számítógéppel támogatott személyes interjú (CAPI - Computer Aided Personal Interview), amely lehetôvé tette többek közt a különbözó árak véletlenszerú, randomizált tesztelését is. A CAPI további előnye volt, hogy a kvótás mintavétel során sikerült pontosan tartani az előírt kvótákat, ezért nem volt szükség az adattábla súlyozására. ${ }^{4}$

A minta elemszáma 400 eset, a tarifacsomag ártesztje során a következő percdíjakat teszteltük: 48, 54, 60, 66, 72, 78 Ft. Az új tarifacsomag jellemzőinek bemutatása után a CAPI segítségével a hat tesztelt ár közül véletlenszerúen feldobott percdíjat mutattunk be az interjúalanyoknak, rákérdezve az előfizetési hajlandóságra. Az igennel válaszolók egy ,fokkal” nagyobb árat kaptak, a nemmel válaszolok pedig egy kisebbet, majd ezután a választól függetlenül az árteszt lezárult. Ennek a kétlépcsős, két árat tesztelő eljárásnak egyik nagy előnye, hogy csaknem megduplázódik a mintaelemszám. (Azért csak majdnem, mivel az első ártesztnél a legalacsonyabb percdíjat elutasítók és a legmagasabb percdíjat elfogadók körében nem teszteltünk újabb árat. Így a két árteszt alapján egymásra épített mintánk az eredeti 400 esetról összesen 729-re növekedett.)

Ennél is fontosabb, hogy ez a kérdezéstechnikai módszer közvetlenül az árkutatási módszer alkalmazhatósága szempontjából is igen szerencsés választásnak bizonyult. Amíg csak a 400-as mintán az elsố árkérdésre adott válaszok alapján építettem fel a logisztikus regresszió modellt, addig a termék ára nem volt szignifikáns hatással a keresletre! Más kutatásban is találkoztam ezzel a piackutató számára igencsak kellemetlen helyzettel, ami jórészt használhatatlanná teszi a kereslet és az optimális ár meghatározására irányuló kutatás eredményeit és hitelteleníti a piackutatót. A két, egymás utáni árat tesztelő módszernek szerencsés tulajdonsága, hogy „,ráirányítja az interjúalany figyelmét” az árra, növeli az árérzékenységet, következésképp az ár szignifikáns hatásának a valószínúségét. Vagyis az a jelenség, hogy az interjúalany felismerve az ártesztet azonnal alkupozícióba helyezkedik, és aminek a hatását többen károsnak tartják (Lyon, 2002), ezúttal szükséges feltételnek bizonyult. A kereslet modellezése bármilyen ökonometriai modellel - logisztikus regresszió egyenlettel - feltételezi, hogy az ár mint független változó együtthatójának szignifikánsan nullától különbözőnek kell lennie. A második árkérdés után további árak tesztelését, vagyis az árlétra alkalmazását értelmetlennek látom, ebben az esetben valóban jelentôsen torzulna az árérzékenység, a keresleti függvény meredeksége.

\section{Modellspecifikáció}

A módszer alkalmazása során az elsố és legfontosabb feladat a binomiális logisztikus regresszió modell specifikációja, amelyben a függó változó a kereslet és a magyarázó változók a termékre, illetve a válaszadóra vonatkozó különböző jellemzók. Ez az egyenlet a termék többváltozós keresleti függvénye, amelyben nemcsak az ár keresletre gyakorolt hatását, hanem további, szignifikáns változók hatását is figyelembe vesszük. A modell felépítése, specifikációja során eldöntendő, hogy milyen kritériumok alapján tartjuk egyik modellt jobbnak a másiknál. A lineáris regresszió modell esetében viszonylag könnyú dolgunk van az $\mathrm{R}^{2}$ vizsgálatával, hasonló kvázi $\mathrm{R}^{2}$ a logisztikus regresszió esetében is van. A specifikációs kritériumok részletes elemzése nélkül két csoportot határozhatunk meg: a likelihood függvény értékén, illetve a modell előrejelzési pontosságán alapuló mutatókét. Ez utóbbi csoportba tartozik a könnyú érthetősége miatt a marketingkutatási gyakorlatban is nagyon népszerú klasszifikációs tábla, ami a függő változó becsült és tényleges értékeit hasonlítja össze. A végsố modell klasszifikációs táblája mellett feltüntettem az ár mint független változó $b_{1}$ paraméterét, és más fontos specifikációs mutatót is (2. táblázat).

2. táblázat

Klasszifikációs tábla

\begin{tabular}{|l|c|c|c|c|}
\hline \multicolumn{2}{|c|}{} & \multicolumn{2}{|c|}{ Becsült } & \multirow{2}{*}{} \\
\cline { 3 - 4 } \multicolumn{2}{|c|}{} & Nem & Igen & \\
\hline \multirow{2}{*}{ Megfigyelt } & Nem & 212 & 58 & $78,5 \%$ \\
\cline { 2 - 5 } & Igen & 26 & 322 & $92,5 \%$ \\
\hline \multicolumn{2}{|l|}{ Teljes találati arány: } & & $86,4 \%$ \\
\hline
\end{tabular}

$b 1=0.032 \quad-2 L L: 420 \quad$ GF:526 $\quad$ Nagelkerke $R^{2}: 668$

Az idevágó ökonometriai szakirodalom meghatározó szerzói egy fontos érvet említenek a klasszifikációs táblából származtatott mutatók alkalmazása ellen, nevezetesen azt, hogy nagymértékben determináltak a függó változó mintabeli eloszlása által. Greene-hez (2003: p. 685.) hasonlóan Hosmer és Lemeshow (2000: p. 157.) is arra hívja fel a figyelmet, hogy a klasszifikációs mutató értékét befolyásolja a függő változó két értékének relatív aránya. Megállapítják, hogy mindig a nagyobb 
elemszámú csoportnak van jobb előrejelzése, és ez olyan szempont, aminek nem sok köze van egy modell illeszkedési jóságához. Vagyis az a marketingkutatók körében elterjedt megállapítás, hogy a logisztikus regresszió jobban jelzi előre a függố változó „,negatív kimenetelét", annak tulajdonítható, hogy a keresleti kutatások többségében gyakoribb a „nem” válasz, a vásárlás elutasítása. Véleményem szerint a marketingkutatási gyakorlatban kihagyhatatlan a klasszifikációs tábla vizsgálata. A módszertani megfontolásokon túl figyelembe kell vennünk, hogy ez a modellünknek egy - a megbízó számára is könnyen értelmezhetô - minôségi mutatója. A fentebb említett probléma - ha nem is kiküszöbölésére, de - figyelembevételére, mérlegelésére ajánlom a tényleges megfigyeléseket és a becsült valószínúségeket összehasonlító hisztogramot.

\section{A binomiális logisztikus regresszió modellspecifikációjának gyakorlati tanulságai}

A modell specifikációja során olyan gyakorlati megállapításokat, javaslatokat fogalmaztam meg, amilyenekkel ökonometriai könyvekben ritkán találkozhatunk, de a gyakorló kutató számára fontosak lehetnek:

1. A legjobb találati aránnyal rendelkezó modellben sok olyan magyarázó változó van, ami nincs szignifikáns hatással a függő változóra, de kontroll alatt tartásuk, indirekt hatásaik kiküszöbölése növeli a modell magyarázó erejét. A modellspecifikáció során megvizsgáltam minden egyes nem szignifikáns változó bevonását, és a végsố modellbe csak azok kerültek be, amelyek növelték a találati arányt. Ez a kérdés ráirányítja a figyelmet a magyarázó változók szelekciójának alkalmazott módszerére. A statisztikai, ökonometriai programok általában, így az SPSS is több eljárást kínálnak a magyarázó változó regressziós modellbe való beléptetésére. Hét ilyen különböző lehetőség adott az SPSS-ben, amelyek - fóképp a lineáris regresszió modell esetében - gyakran ugyanazt a modellt eredményezik, de esetünkben van jelentősége a modellszelekciós eljárásnak. A köztük levô egyik különbség az, hogy az ENTER módszer a modellben hagyja a nem szignifikáns változókat is, de az SPSS kínálta másik hat módszer nem.

A modellszelekciós eljárások összehasonlítása során megállapítottam, hogy az ENTER módszer eredményezi a legjobb modellt, de ennek megvan - a marketingkutatásban igencsak sokat jelentó - ára; a modellspecifikáció időigénye sokszorosa a többiekének. Egyenként meg kell ugyanis határozni valamennyi nem szignifikáns független változó esetében, hogy a modellbe való bevonásuk vagy kihagyásuk növeli-e jobban a találati arányt. Kérdés, hogy egy szoros határidốbe préselt piackutatási projekten belül érdemes-e az egy-két százalékponttal jobb találati arányt eredményezô, de sokkal időigényesebb ENTER módszert választani.

2. Kategoriális független változó használatával jobb találati eredményt érünk el, mint ugyanannak az ismérvnek „magasabb mérési szintư” numerikus változójával. Gyakorlatilag érdemes átalakítani a numerikus változót kategoriálissá. Ennek az adatelemzésben szokatlan kijelentésnek a magyarázata abban áll, hogy a független változó (pl. jövedelem) hatása nem lineáris, hanem vannak olyan kategóriák (pl. jövedelemszintek), amelyek - a többi magyarázó változó adott szintje mellett - szignifikáns hatással vannak, más kategóriák pedig nem.

3. A modell találati arányát növeli, ha a kategoriális magyarázó változóknak minél több értéke, kategóriája van. A piackutatásban, adatelemzésben gyakran előfordul, hogy a viszonylag több kategóriával rendelkező nominális változókat ,visszakódolják” kevesebb kategóriájú változóvá, a binomiális logisztikus regresszió modellspecifikációjánál ezt nem ajánlott.

\section{Az optimumár meghatározása}

A klasszifikációs tábla (2. táblázat) alapján a modellspecifikáció sikeresnek tekinthető, a modell 92,5\%-os biztonsággal jelzi elôre a szolgáltatás iránti keresletet, az összes találati arány pedig $86,4 \%$. A végső modell eredményeit: független változóit, paramétereit és azok statisztikáit terjedelmük miatt nem részletezem, a módszer szempontjából legfontosabb eredmény, hogy a szolgáltatás árát jelentô percdíj változó együtthatója 0,034, szignifikánsan különbözik nullától. Ez a módszer olyan elengedhetetlen feltétele, amelyet a kutató nem tud befolyásolni, és enélkül használhatatlanná válna az egész kutatás. A modellspecifikáció, a legjobb modell megtalálása után a már ismert képlet alapján határozzuk meg az optimumárat:

$$
p_{o}=x=\frac{1}{b \cdot\left(\mathrm{y}^{*}-1\right)}
$$

Az optimumár kiszámításához szükséges $b$ paramétert meghatározzuk a becslési eljárás során, de mi lesz az $y^{*}$ értéke? A vásárlás becsült valószínúsége $\left(y^{*}\right)$ értéke esetról-esetre változik, ahogy a magyarázó változók különböző rögzített értéket vesznek fel, de az optimumár képletébe egyetlen, az egész mintára érvényes értékre van szükségünk. Kézenfekvő megoldásnak túnik, hogy az esetenként változó értékek min- 
tabeli átlagával számoljunk. Ezt ajánlják a logisztikus regressziót tárgyaló szakirodalomban (Greene, Hosmer - Lemeshow stb.) egy független változó marginális hatásának kiszámolására, és figyelembe véve, hogy az árrugalmassági együtthatót, majd az optimumárat az ár marginális hatásából kiindulva fejeztük ki, indokoltnak túnik ez a módszer. Azonban elméletileg könnyen belátható az a probléma, hogy nagyon eltérô vásárlási hajlandóságok, a becsült vásárlási valószínúségek eltérô eloszlásai ugyanazt az átlagos keresletet eredményezik. A 0,56-os átlag úgy is kijöhet, hogy az esetek 95\%-ának a vásárlási valószínúsége 0,5 felett van, de akár fordítva is. Általánosabban fogalmazva, az átlag nem elégséges statisztika egy eloszlás jellemzésére. Ennél jobb alternatívának kínálkozik a vásárlók becsült arányával, a küszöbértéknél $(0,5)$ nagyobb becsült valószínúségek arányával való számolás. A legjobb számítási mód megtalálását még a módszer nyitott kérdésének tartom, de a jelenlegi kipróbáltsági szinten a második alternatívát ajánlom. A kereslet becsült mérték és az árváltozó paraméterét behelyettesítve a fenti képletbe közvetlenül meghatározhatjuk az optimumárat $(64,2 \mathrm{Ft})$.

\section{A keresleti függvény empirikus meghatározásán alapuló árkutatási módszer}

A második javasolt árkutatási módszer, a keresleti függvény empirikusan meghatározásán alapuló módszere a `60-as években kidolgozott Gabor-Granger'-modell továbbfejlesztésének tekinthetô, amelyben a kinyilvánított ár-kereslet pontok alapján meghatározzák a keresleti és az árbevételi függvényt, majd azt az árat tekintik optimálisnak, amelyiknél az árbevételi görbe eléri maximumát. A módszer „,mottójának” is tekinthetjük azt, amit Clive W. J. Granger a Nobel-díj átvételekor tartott beszédében (2003) mondott: „úgy hiszem, hogy jobb a mikroökonómiai elméletet a valós gazdasági életben tesztelni, mint azt hinni, hogy alkalmazhatatlan."

A továbbfejlesztésben megóriztem az ároptimalizációs célt, de törekedtem a gyakorlati alkalmazás minél egzaktabb kidolgozására is. Nem grafikus úton keresem az ár-kereslet pontokból képzett árbevételi görbe maximumát, hanem a legkisebb négyzetek módszerével függvényt illesztve határozom meg a keresleti függvényt. A mérhetô pontosságú $\left(\mathrm{R}^{2}\right)$ függvényillesztésen túl a módszer eredetisége abban áll, hogy felhasználok egy rég ismert mikroökonómiai összefüggést: az árrugalmassági együttható egyenlő mínusz egy öszszefüggésból kifejezem a maximális árbevételt biztosító optimumárat. Ennek képletét levezettem az SPSS függvényillesztési opciója által alkalmazott valameny- nyi (tizenegy) függvénytípusra, de a legjobb illeszkedésre általában a másod, és harmadfokú polinomiális és az exponenciális függvény esetében számíthatunk. Az egyéni hozzáadott érték tehát az optimumár matematikai levezetésében és a számítási részletek egzaktabb kidolgozásában áll. Elmondható, hogy a logisztikus regresszió modellen alapuló árkutatási módszer ellenơrzésére „mellékesen” létrehozott függvényillesztés módszere több szempontból is önmagában alkalmazható árkutatási módszernek tekinthetô. Olyan technikákból áll össze, amelyeket külön-külön már régóta ismernek és alkalmaznak, de ezek együttes alkalmazása és az optimumár képletének kifejezése jelenti az újszerúséget. A módszer előnye leginkább gyors és egyszerú alkalmazásában áll, korlátjának is az egyszerúsége, kétváltozós jellege tekinthető.

\section{A keresleti függvény meghatározásán alapuló árkutatási módszer empirikus próbája}

A módszer alkalmazását egy 2008-as kutatáson keresztül mutatom be, amely egy kis üzleti vállalkozás stratégiai kérdéseire keresett választ. A vállalkozás résztulajdonosa egy Magyarországon már létezô webáruházának romániai megnyitását tervezte. A forgalmazott termékek - importált, üzletekben nem kapható, speciális női kozmetikai cikkek - a célcsoport és annak elérhetósége miatt érdekesek. A kutatás jellemzói:

- cél: a marketingstratégia megalapozása, mindenekelőtt a termék beárazása.

- on-line (webes) kérdőív a termékek (nyolc termék) árára, a kiszállítás módjára, idejére vonatkozó kérdésekkel. ${ }^{6}$

- minta: 200 (25-50 év közötti nô), iwiwról és más közösségi oldalakról, illetve szépségápolási témájú internetes fórumokról toborzott interjúalanyok. Mint általában, ezúttal is problematikus egy pontosan még nem meghatározott célpiacú új termék bevezetésénél a mintavétel reprezentativitását vizsgálni és megítélni. Mivel nem rendelkeztünk az alapsokaságra vonatkozó semmilyen információval, ezért önkényes mintavételi módot választottunk.

- kérdezéstechnika: az árra vonatkozó kérdéseket úgy tettük fel, hogy referenciaárként előbb teszteltük a magyarországi piaci árat, majd ha az interjúalany nem fogadta el, akkor nyitott kérdéssel kérdeztük, hogy mennyit lenne hajlandó fizetni.

E kutatás rámutat arra is, hogy egy családi vállalkozás marketinget tanult tulajdonosa is kis költséggel nagyon fontos keresleti információkhoz juthat. 


\section{A keresleti függvény illesztése}

A kutatás során tesztelt nyolc termék közül az egyiken mutatom be a módszer alkalmazását. A kereslet ár függvényében való megjelenítésének grafikus ábrázolása maga a keresleti görbe, amely meghatározására és ábrázolására több alkalmas szoftver használható, a következókben én az SPSS függvényillesztés módszerét használom. A keresletet kifejezhetjük az abszolút gyakorisággal is, ebben az esetben pontosan megfelel a keresleti függvény definíciójának, illetve alkalmazható a relatív gyakoriság is. Mivel az utóbbit egy lépéssel könnyebb rávetíteni a teljes alapsokaságra, ezért az utóbbival számolok.

A különböző kinyilvánított árakhoz (40-106 RON) tartozó keresletet az inverz kumulált relatív gyakoriság jelenti. Ez természetesen azt az implicit feltételt is tartalmazza, hogy a fogyasztó racionális, és a termék nem minősül luxusjószágnak, vagyis aki például $55 \mathrm{RON}$-ért megvenné a terméket az 40 RON-ért is megveszi. Az ár és a hozzá tartozó kereslet pontpárok meghatározása után az SPSS függvényillesztés (Curve Estimation) módszerét alkalmazva keressük a legjobban illeszkedő keresleti függvényt (3. táblázat).

$$
Q=\mathrm{b}_{0}+\mathrm{b}_{1} \cdot \mathrm{p},
$$

ahol $Q$ a keresleti függvény, $\mathrm{p}$ az ár, $\mathrm{b}_{0}$ és $\mathrm{b}_{1}$ paraméterek. Behelyettesítve a lineáris keresleti függvény általános alakját az előbbi összefüggésbe, kifejezzük az optimum árat:

$$
\begin{aligned}
& \varepsilon_{p}=\frac{\delta Q}{\delta p} \cdot \frac{p}{Q}=b_{1} \cdot \frac{p}{b_{0}+b_{1} \cdot p}=-1 \\
& p=-\frac{b_{0}}{2 b_{1}}
\end{aligned}
$$

$\mathrm{Az}$ 1. ábrán szemmel is láthatóan a lineáris függvénynél lényegesen jobban illeszkednek a különböző nemlineáris függvények, tapasztalatom szerint általában a harmadfokú polinomiális illeszkedik a legjobban. A 4. táblázatban kifejezem az optimumár képletét az SPSS által alkalmazott valamennyi (tizenegy) függvénytípusból, ezúttal már levezetés nélkül.

Öt függvénytípus esetén egyértelmúen kifejezhetô az optimumár képlete, emellett három másiknál a pa-

A termék ára és kereslete

\begin{tabular}{|l|c|c|c|c|c|c|c|c|c|}
\hline ár (RON) & 40 & 45 & 50 & 55 & 60 & 70 & 80 & 97 & 106 \\
\hline inverz kumulált relatív gyakoriság & $49 \%$ & $46 \%$ & $45 \%$ & $37 \%$ & $35 \%$ & $33 \%$ & $26 \%$ & $21 \%$ & $20 \%$ \\
\hline
\end{tabular}

Öt különböző függvénytípus illeszkedését láthatjuk az 1. ábrán. Az alkalmazott statisztikai szoftverrel összesen tizenegy függvénytípust próbálhatunk ki, de az áttekinthetőség kedvéért csak az öt legjobban használhatót tüntettem fel.

\section{Az optimális ár analitikus levezetése}

A függvényillesztés után a módszer következő lépése a kiválasztott függvénytípusból levezetni az árrugalmassági együtthatót és kiszámolni az optimumárat. Amint az előzô módszernél is láttuk, az árbevétel maximalizálása melletti optimumár ott határozható meg, ahol az árrugalmassági együttható egyenlő -1-gyel.

$$
\varepsilon_{\mathrm{p}}=\frac{\delta \mathrm{Q}}{\delta \mathrm{p}} \cdot \frac{\mathrm{p}}{\mathrm{Q}}=-1
$$

Legegyszerúbb dolgunk természetesen akkor van, ha a lineáris függvénnyel fejezzük ki a keresleti függvényt:

1. ábra

\section{A keresleti görbe illesztése öt függvénytípussal}

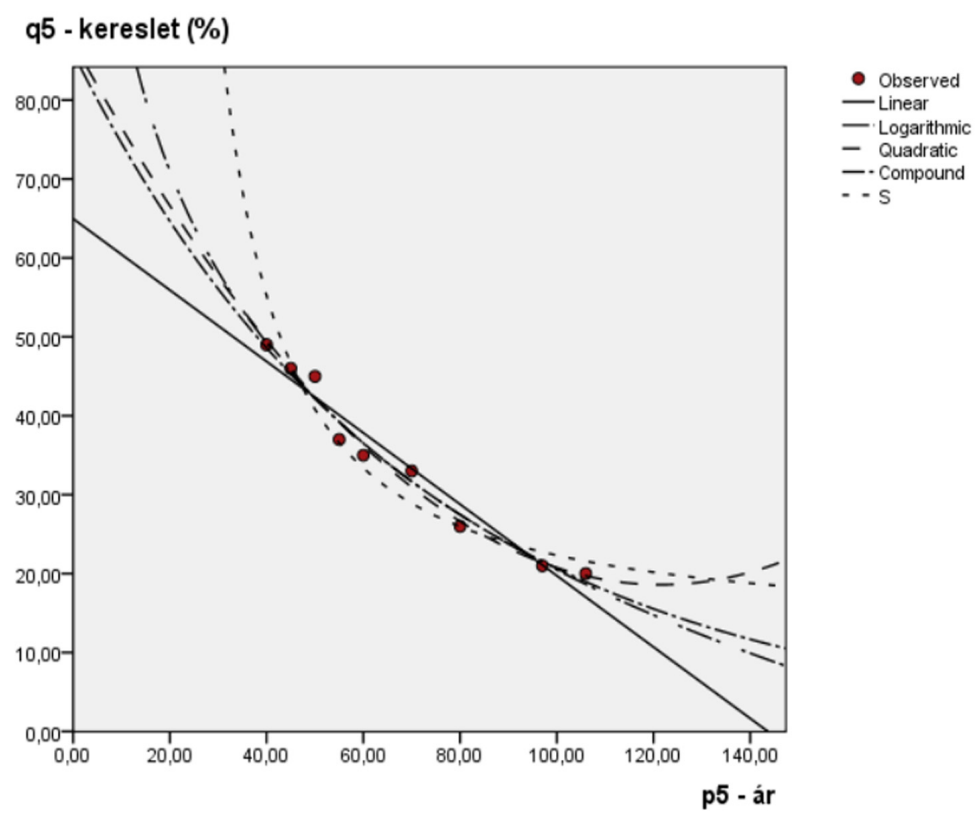


Az optimumár képlete különbözố típusú keresleti függvények esetén

\begin{tabular}{|c|c|c|c|}
\hline & A függvény általános formája & Az optimumár képlete & Megjegyzés \\
\hline Lineáris & $Q=b_{0}+b_{1} \cdot p$ & $p=-\frac{b_{0}}{2 b_{1}}$ & - \\
\hline $\begin{array}{l}\text { Másodfokú } \\
\text { polinomiális }\end{array}$ & $Q=b_{0}+b_{1} \cdot p+b_{2} \cdot p^{2}$ & $p_{1,2}=\frac{-2 b_{1} \pm \sqrt{4 b_{1}^{2}-12 b_{2} \cdot b_{0}}}{6 b_{2}}$ & - \\
\hline $\begin{array}{l}\text { Exponenciális } 1 . \\
\text { (Compound) }\end{array}$ & $Q=b_{0} \cdot b_{1}{ }^{p}$ & $\mathrm{p}=-\frac{1}{\ln b_{1}}$ & - \\
\hline $\begin{array}{l}\text { Exponenciális } 2 . \\
\text { (Growth) }\end{array}$ & $Q=\mathrm{e}^{\mathrm{b}_{0}+\mathrm{b}_{1} \cdot \mathrm{p}}$ & $b_{1} \cdot p=-e^{b_{1} \cdot p-p}$ & $\begin{array}{c}\text { nem lehet } p \text { általános képletét kifejezni, } \\
\text { de a } b_{1} \text { paraméter ismeretében meghatározható }\end{array}$ \\
\hline Logaritmikus & $Q=b_{0}+b_{1} \cdot \ln p$ & $p=e^{\left(\frac{-b_{1}-b_{0}}{b_{1}}\right)}$ & \\
\hline $\begin{array}{l}\text { Harmadfokú } \\
\text { polinomiális }\end{array}$ & $Q=b_{0}+b_{1} \cdot p+b_{2} \cdot p^{2}+b_{3} \cdot p^{3}$ & - & $\begin{array}{c}\text { ha van valós megoldás, akkor egyértelmúen } \\
\text { meghatározható }\end{array}$ \\
\hline $\begin{array}{l}\text { Exponenciális } 3 . \\
\text { (S function) }\end{array}$ & $Q=b_{0} \cdot e^{b_{0}+\frac{b_{1}}{p}}$ & $p=b_{1}$ & \\
\hline $\begin{array}{l}\text { Exponenciális } 4 . \\
\text { (Exponential) }\end{array}$ & $Q=b_{0} \cdot e^{b_{1} \cdot p}$ & $b_{1} \cdot p=-e^{b_{1} \cdot p-p}$ & $\begin{array}{c}\text { nem lehet } p \text { általános képletét kifejezni, } \\
\text { de a } b_{1} \text { paraméter ismeretében meghatározható }\end{array}$ \\
\hline Inverz & $Q=b_{0}+\frac{b_{1}}{p}$ & $b_{0} p=0$ & $\begin{array}{l}\mathrm{b}_{0} \neq 0 \text { értéknél csak a } \\
\mathrm{p}=0 \text { megoldása van }\end{array}$ \\
\hline Hatványkitevôs & $Q=b_{0} \cdot p^{b_{1}}$ & $b_{1}=-1$ & végtelen sok megoldása van $p$-re \\
\hline Logisztikus & $\begin{array}{l}Q=\frac{1}{\frac{1}{k}+b_{0} b_{1}^{p}} \\
\text { ahol } k \text { egy a priorı detınıált küszöbérték }\end{array}$ & $\mathrm{p} \cdot \ln \mathrm{b}_{1}-1=\frac{\mathrm{b}_{1}^{-\mathrm{p}}}{\mathrm{b}_{0} \cdot \mathrm{k}}$ & $\begin{array}{l}\text { nem lehet } p \text { általános } \\
\text { képletét kifejezni, de a } b \text { paraméterek } \\
\text { ismeretében meghatározható }\end{array}$ \\
\hline
\end{tabular}

raméterek ismeretében megoldható az egyenlet. Az általában legjobb illeszkedést eredményezô harmadfokú polinomiális függvény esetében a képlet kissé hosszadalmas, de valamilyen matematikai szoftver (MATLAB, MAPLE), vagy akár az Excel Solver funkciójával gyorsan megoldható. Az öt legkönnyebben kezelhető függvény illeszkedési jóságának mutatóját $\left(\mathrm{R}^{2}\right)$, paramétereit és a kiszámolt optimumárakat az 5. táblázatban találjuk.

Közel egyforma eredmények jöttek ki, ami pozitívan befolyásolja a módszer elfogadhatóságát és a múködóképességébe vetett bizalmat. Jelentôsen eltéró optimumárak esetén egy marketingkutató nehezen győzné meg a klienst a módszer helyességéról. Rosszabb illeszkedésú függvények esetén ez a probléma könnye- dén előállhat, a legkevésbé jó illeszkedésú $\mathrm{S}$ függvény optimumára jobban eltér a többitől. A viszonylag kis különbségek ellenére is egy optimumárat kell választanunk az öt közül. Kézenfekvő választási elvnek túnik, hogy a legjobban illeszkedő (legnagyobb $\mathrm{R}^{2}$-û́) függvény alapján számított érték legyen az optimális. Esetünkben a másodfokú polinomiális és az exponenciális függvény tekinthetô ennek, a másodfokúnak - értelemszerúen - két megoldása is van. Ezek közül a 64,6-os érték tûnik valószerúbbnek, ami már számottevô mértékben különbözik az exponenciális függvény 69,9-es értékétól. Ezért a többi értéket is figyelembe véve 70,0 RON-os árban határoztam meg az árbevétel maximalizálása szempontjából optimális árat, vagy ha pszicho-

Ugyanazon termék különbözó keresleti függvényeiból számolt optimum árai

\begin{tabular}{|l|c|c|r|r|r|}
\hline & $\mathbf{R}_{\mathbf{2}}$ & $\mathbf{b}_{\mathbf{0}}$ & $\mathbf{b}_{\mathbf{1}}$ & $\mathbf{b}_{\mathbf{2}}$ & $\mathbf{p}_{\mathbf{0}}$ \\
\hline Lineáris & 0,948 & 64,96 & $-0,452$ & & $\mathbf{7 1 , 8}$ \\
\hline Másodfokú & 0,980 & 87,37 & $-1,132$ & 0,0047 & $\mathbf{9 5 , 9 / 6 4 , 6}$ \\
\hline Exponenciális (Compound) & 0,980 & 85,92 & 0,986 & & $\mathbf{6 9 , 9}$ \\
\hline Logaritmikus & 0,977 & 165,05 & $-31,394$ & & $\mathbf{7 0 , 6}$ \\
\hline S függvény & 0,937 & 2,502 & 60,363 & & $\mathbf{6 0 , 3}$ \\
\hline
\end{tabular}




\section{A koordináta rendszer eltolása}

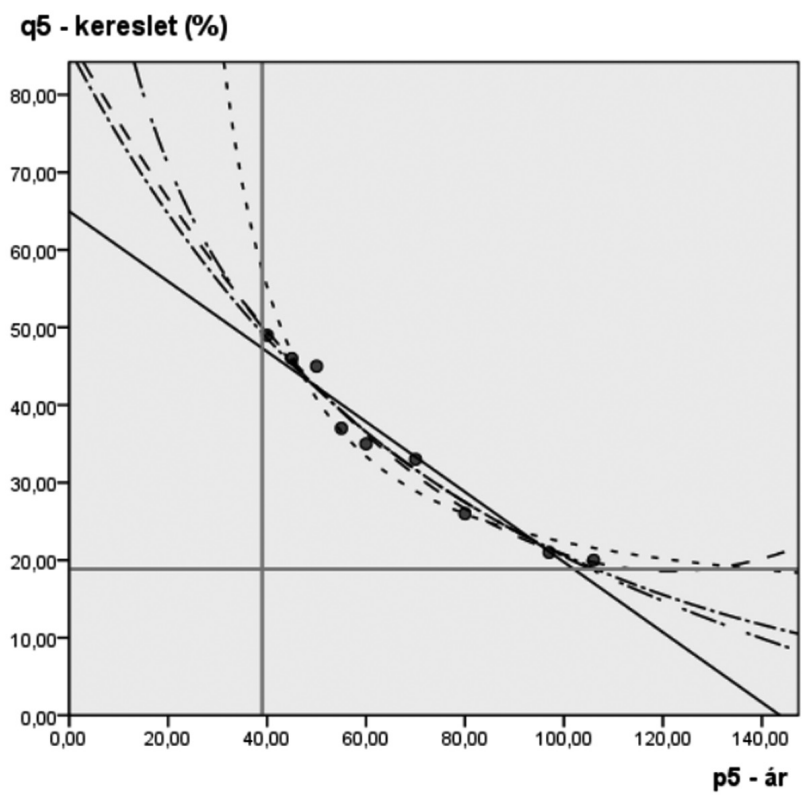

lógiai árat kívánunk alkalmazni, akkor 69 RON-ban. A szóban forgó kutatás során a módszer helyességének megállapítására külsô, benchmark adatok viszonyítási alapja is rendelkezésemre áll. Mivel olyan termékekról van szó, amelyeket a magyarországi piacon már forgalmaznak, ezért a román piacra kiszámított optimumárakat viszonyíthatom a már „múködő” magyarországi árakhoz. Mind a nyolc termék esetében összehasonlítottam az egyik legjobb illeszkedést mutató és könynyen számolható másodfokú polinomiális függvénnyel kiszámolt optimumárakat a magyarországi árakkal. A kinyilvánított keresleten alapuló, romániai optimumárak nagyon valószerúeknek, „múköodóképeseknek” túnnek, nem sokkal a magyarországi piaci ár alatt. A két piac árai közötti átlagos eltérés 14,6\%, ami könnyen magyarázható a két piac közötti különbségekkel is.

Egy pontban felmerül a módszer fejlesztésének, módosításának szükségessége. Az előbbi grafikont (1. ábra) vizsgálva megállapítható, hogy némelyik függvény - pl. a legjobb illeszkedést adó másodfokú, vagy más nemlineáris függvény - bal oldali vége nagyon „felmegy”, magas értéknél metszi a függőleges tengelyt. Ez azt a természetes helyzetet tükrözi, hogy alacsony áron nagy a kereslet. A lineáris függvény nullparamétere 64,9, ezzel szemben a másodfokúé 87,4, ami jelentős különbség, de igazából logikailag is értelmezhetetlen, hogy nulla áron mekkora lenne a ke-
2. ábra reslet. ${ }^{7}$ Jogos elvárásnak túnik, hogy a becslés során a legkisebb ár alatti és a legnagyobb ár feletti tartománnyal lehetóleg ne befolyásoljuk a függvényillesztést (2. ábra).

A gyakorlatban ez úgy valósítható meg, hogy a tesztelt árakból levonjuk a legkisebb értéket, majd a függvényillesztés és az optimumár meghatározása után hozzáadjuk a végeredményhez. Technikai szempontból indokolt, hogy ne nulla árnál, hanem 1-nél legyen a legnagyobb mért kereslet, mivel néhány függvénytípus nem metszi a függóleges tengelyt (3. ábra). Az új koordináta rendszerben újrafuttatva a függvényillesztéseket, a 6. táblázatban látható eredményeket kapjuk.

A lineáris, másodfokú polinomiális és az exponenciális függvények esetében az illeszkedés jósága nem változott, de a másik két függvénynél jelentősen csökken. Nem meglepő, hogy a lineáris függvény esetében a meredekség nem változik, ahogy a másodfokú polinomiálisnál az x² együtthatója sem. A 6. táblázatban összehasonlítom a két módszer; a transzformáció nélküli és a koordináta rendszer eltolása utáni eredményeit.

A jó illeszkedésú függvények eredeti és transzformáció utáni optimumárai szinte teljes mértékben megegyeznek, ezért továbbra is a 70 RON-os végeredményt tartottam a jó megoldásnak. Ezután joggal merül fel a kérdés, hogy egyáltalán szükség van-e erre a transzfor-

\section{A vizsgált függvények újraillesztése az új koordináta rendszerben}

\section{q5r - kereslet (\%)}

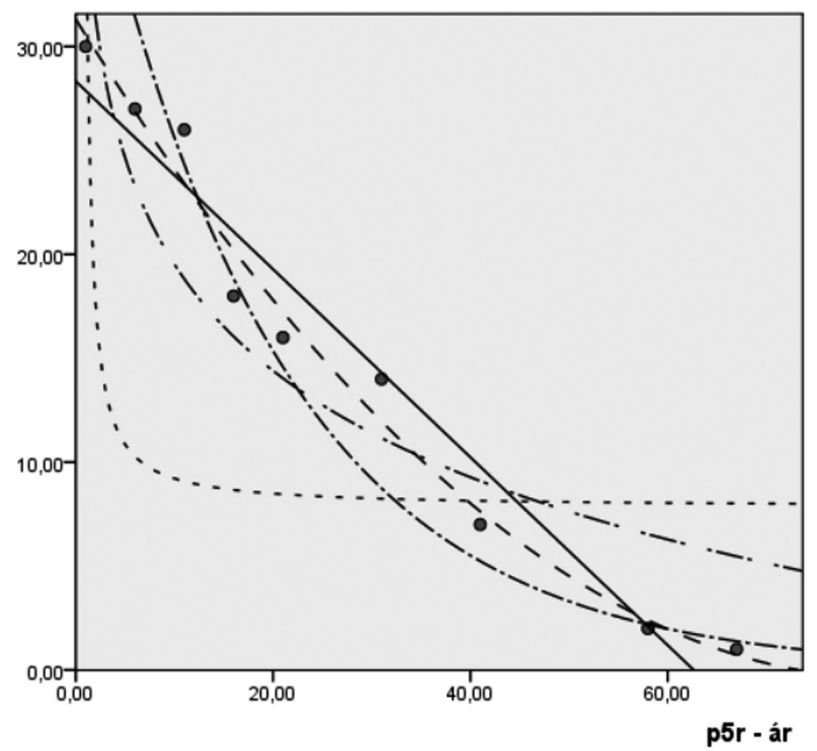

3. ábra

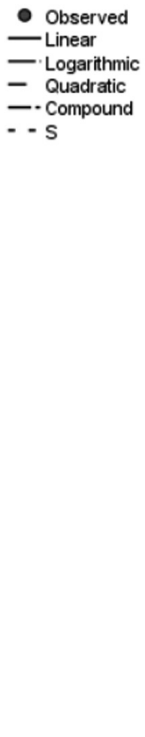


Ugyanazon termék skálatranszformáció előtti és utáni optimumárai

\begin{tabular}{|l|c|c|c|c|}
\hline \multirow{2}{*}{} & \multicolumn{2}{|c|}{ Transzformáció nélkül } & \multicolumn{2}{c|}{ A koordináta rendszer eltolásával } \\
\cline { 2 - 5 } & $\mathbf{R}_{\mathbf{2}}$ & Optimumár & $\mathbf{R}_{2}$ & Optimumár \\
\hline Lineáris & 0,948 & $\mathbf{7 1 , 8}$ & 0,948 & $\mathbf{7 0 , 3}$ \\
\hline Másodfokú & 0,980 & $\mathbf{6 4 , 6}$ & 0,980 & $\mathbf{6 6 , 2}$ \\
\hline Exponenciális (Compound) & 0,980 & $\mathbf{6 9 , 9}$ & 0,980 & $\mathbf{5 8 , 5}$ \\
\hline Logaritmikus & 0,977 & $\mathbf{7 0 , 6}$ & 0,818 & $\mathbf{9 0 , 7}$ \\
\hline S függvény & 0,937 & $\mathbf{6 0 , 3}$ & 0,183 & $\mathbf{4 0 , 6}$ \\
\hline
\end{tabular}

mációra? A multidimenzionális modellekkel szemben a függvényillesztés módszerénél jelentôsége van azillesztett függvény és az ordináta metszéspontjának, vagyis a függvény nullparaméterének. Láthattuk a különböző függvénytípusok optimumárképleteiben, hogy többnél is a nullparaméter befolyásolja az optimumárat: lineáris, másodfokú, harmadfokú polinomiális, logaritmikus és logisztikus. Véleményem szerint a skálatranszformáció indokolt, ezt támasztja alá a következố empirikus kísérlet is.

\section{A két módszer összehasonlítása}

A keresleti függvény empirikus meghatározásán alapuló módszert kipróbáltam a logisztikus regresszió modell empirikus kutatási adatain is (első empirikus kutatás). Ezúttal tehát nem egy multidimenzionális függvény, hanem a mobiltelefon-szolgáltatás percdíja és a kereslete közötti összefüggés jelenti a keresleti görbét. A különböző függvénytípusok kipróbálása a 4. ábrán látható illeszkedéseket eredményezte.

Megfigyelhető, hogy a keresleti görbék nagyon „magasan kezdenek”, ennek mértékét a polinomiális függvények esetében $a b_{0}$ paraméterek pontosan számszerúsítik is (7. táblázat). Mivel a keresletet százalékos formában rögzítettuik, ezért joggal feltételezhető, hogy az ingyen adott tarifacsomagok esetében sem lenne a kereslet a célpiac 128\%-a, mint ahogy azt a lineáris keresleti függvény mutatja. Indokolt az előzőekben említett skálatranszformáció, és ezt igazolják az alábbi táblázatban feltüntetett eredmények is.

A legjobban illeszkedő másodfokú polinomiális függvény alapján számított optimumár 63,3 Ft, ami gyakorlatilag nem különbözik a binomiális logisztikus modellen alapuló árkutatási módszer 64,2 Ft-os értékétől.
Az eredmények összehasonlítása után vizsgáljuk meg a két módszer közötti elméleti különbségeket. A kereslet függvény meghatározásának módszere - egy piackutatási projekt esetében nagyon lényeges - előnyökkel kecsegtet, mivel nem igényel összetett modellspecifikációt, ezért lényegesen egyszerúbb és gyorsabb, mint a többváltozós modell. Kérdés, hogy nem veszítünk-e el lényeges információt, ha a keresletet meghatározó tényezók közül csak az árat vesszük figyelembe és mellőzzük a többi lehetséges faktort? A módszer egyváltozós jellegébő́l adódóan ellenérvként felmerülhet, hogy azzal, hogy csak az árat vesszük figyelembe a keresletet meghatározó tényezók közül, lényeges információkat veszíthetünk el. Ezzel szemben miért kell bármit is hozzátenni a potenciális vásárló által kinyilvánított árhoz? Az árkutatások alapvetô feltételezése,

\section{Az elsố empirikus kutatás a függvényillesztés módszerével}

\section{4. ábra}

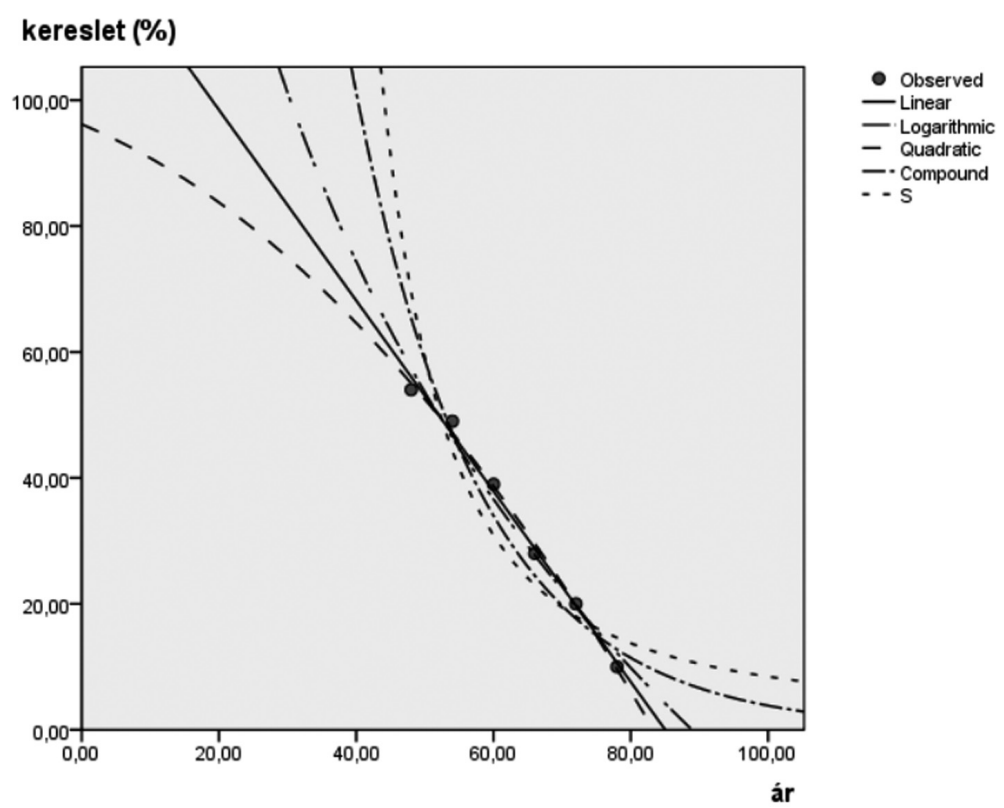


Transzformáció elôtti és utáni optimumárak öt függvénytípusra

\begin{tabular}{|l|l|c|c|c|c|c|}
\hline \multicolumn{2}{|c|}{} & $\mathbf{R}^{\mathbf{2}}$ & $\mathbf{b}_{\mathbf{0}}$ & $\mathbf{b}_{\mathbf{1}}$ & $\mathbf{b}_{\mathbf{2}}$ & $\mathbf{p}_{\mathbf{0}}$ \\
\hline \multirow{2}{*}{ Lineáris } & Eredeti & 0,993 & 128,733 & $-1,5143$ & 42,5 \\
\cline { 2 - 7 } & Transzformált & 0,993 & 48,560 & $-1,5143$ & $\mathbf{6 3 , 0}$ \\
\hline \multirow{2}{*}{$\begin{array}{l}\text { Másodfokú } \\
\text { (Componenciális }\end{array}$} & Eredeti & 0,995 & 96,150 & $-0,4518$ & $-0,0084$ & 46,4 \\
\cline { 2 - 7 } & Transzformált & 0,995 & 47,2886 & $-1,2444$ & $-0,0084$ & $\mathbf{6 3 , 3}$ \\
\hline \multirow{2}{*}{ Logaritmikus } & Eredeti & 0,926 & 896,023 & 0,9469 & & 18,3 \\
\cline { 2 - 7 } & Transzformált & 0,769 & 88,8147 & 0,8947 & & $\mathbf{5 6 , 0}$ \\
\cline { 2 - 7 } & Eredeti & 0,980 & 417,778 & $-93,0950$ & & 32,7 \\
\hline \multirow{2}{*}{ S függvény } & Eredeti & 0,753 & 51,8292 & $-11,6940$ & & $\mathbf{7 7 , 9}$ \\
\cline { 2 - 7 } & Transzformált & 0,197 & 0,1862 & 194,7090 & & 194,7 \\
\hline
\end{tabular}

hogy a fogyasztó rezervációs árát meghatározó összetett rendszer (Monroe, 1990) végeredménye megjelenik a vásárlási hajlandóság kinyilvánításában, és ez az árkutatás szempontjából elégséges. Ezzel szemben az ökonometriai, és ezen belül a binomiális logisztikus regresszió modell beépíti valamennyi - a kutatás tervezése során figyelembe - keresletet meghatározó tényezôt. Végeredményben a két modell együttes alkalmazását javaslom, ha ez lehetséges, de a függvényillesztés módszerét is önmagában életképesnek tartom, amenynyiben a kutatási terv, elsôsorban a kérdőív rövidsége ezt indokolja.

\section{Továbbfejlesztési lehetôségek}

A függvényillesztés módszerének továbbfejlesztési lehetőségeit elsősorban más módszerekbe való beépítésében látom, például használható lehet a Conjointelemzésben feltárt ár-kereslet összefüggés kiegészító, egydimenziós elemzésére. A binomiális logisztikus regresszió modellen alapuló árkutatási módszer a többi kategoriális és korlátozott eredményváltozójú modellre is kifejleszthetô. Például a korlátozott eredményváltozójú modellek gyakran alkalmazott típusára, a James Tobin, Nobel-díjas közgazdász által a tartós fogyasztási cikkek keresletének elemzésére kifejlesztett ún. tobit modellre is alkalmazható. Indokolt a multinomiális logit modell használata is, mivel a függó változó kategoriális jellege nagyon valószerú vásárlási helyzetek modellezésére alkalmas. Természetesen e modellnél is specifikus ökonometriai problémákkal találkozhatunk: az egyik ilyen eróteljes feltevés az, amit Irreleváns Alternatívák Függetlenségeként (Independence of Irrelevant Alternatives) ismer a szakirodalom. E prob- léma lehetséges megoldásának ígérkezik az ún. mixed logit modell.

A marketingkutatási problémák is jelentôsek; az árrugalmassági együtthatóhelyett valószínúleg kereszt-árrugalmasságot kell vizsgálnunk, mivel a multinomiális logit egy alternatíva választásának valószínúségét más alternatívákhoz viszonyítva számszerúsíti, és nem a vásárlás elutasításához. A multinomiális logisztikus regresszión alapuló árkutatási módszertan valószínúleg nagyon sok hasonlóságot fog mutatni az egyre népszerúbb Choice Based Conjoint-tal. További kategoriális és korlátozott eredményváltozójú modellek is adaptálhatók, például a probit modell, de ennél a határhatás kiszámítása technikailag meglehetősen nehéz és roszszul értelmezhetố, ennek megfelelően az árrugalmassági együttható, illetve az optimumár kiszámítása is az. A többváltozós módszer továbbfejlesztési lehetôségének másik iránya az idósoros ökonometria alkalmazása, az idôtényező mint független változó beépítése a keresleti modellbe. Ennek a fejlesztésnek komoly gyakorlati jelentősége lehet, mivel a tényleges keresleti adatok jellemzően idôsoros adatok. Amennyiben sikerül az időtényezô mellett a modellbe megfelelően beépíteni a változó környezeti és marketingmixelemeket, akkor erós eszköze lehet a marketing információs rendszereknek és a vállalati árpolitikának.

\section{Lábjegyzet}

${ }^{1}$ A logisztikus regresszió modellbe is ugyanazzal a dummy-zásnak
nevezett eljárással kerülnek be a kategoriális változók, mint a li-
neáris modellnél, de amint a késóbbiekben bemutatom, ez a nem-
lineáris modelleknél sokkal jobban múködik.
${ }^{2}$ Érdekes példát említ a szerzó saját kutatási gyakorlatából: ,egy
nagy szállodalánc megbízásából végzett kutatás eredménye sze- 
rint a szoba árát 15 \$-ról 25\$-ra emelhetik, ha biztosítanak parkolóhelyet. Válaszul a szálloda menedzsmentje rámutatott, hogy 6 \$ és 8 \$ közötti összegért lehet parkolni a szálloda oorzött parkolójában, és ami még rosszabb, a vendégek csak 20\%-a jön autóval" (Lyon, 2002).

${ }^{3}$ Csökkenő meredekségú keresleti görbét, ezáltal konkáv árbevételi görbét feltételezve nem szükséges a pozitív másodrendú deriváltra vonatkozó feltétel ellenőrzése.

${ }^{4}$ Ennek azért van jelentősége, mert a nemlineáris modelleknél, így a logisztikus regressziónál is, a súlyozás kérdése problémásabb, mint a lineáris regressziónál.

${ }^{5}$ Az 1960-as években kifejlesztett módszer André Gabor közgazdász, gazdaságpszichológus és Clive W. J. Granger ökonométer nevéhez füződik (Gabor - Granger, 1964). André Gabor (19031990), Gábor Dénes Nobel-díjas fizikus, a hologram feltalálójának öccse, Budapesten született, majd 1938-ban követte bátyját Angliába, ahol az államigazgatásban, majd a Nottingham-i Egyetemen dolgozott. A berlini és a londoni egyetemen közgazdaságtant tanult, nemzetközi, szakmai ismertséget az árra vonatkozó kutatásai eredményeztek. Clive W. J. Granger (1934-2009) és Robert F. Engle magukat ökonométernek definiáló tudósok közösen vehették át a 2003-as közgazdasági Nobel-díjat. Az elismerés nem ezért a modellért, hanem az idősoros ökonometria területén kifejtett nagy ívú munkásságáért járt, ô alkotta meg az autoregresszív feltételes heteroszkedaszticitás (ARCH) fogalmát is.

${ }^{6}$ Ezúton is köszönetemet fejezem ki Szakáts Zsuzsának, volt diákomnak, a web áruház résztulajdonosának az on-line adatgyứjtés szakszerúségéért.

${ }^{7}$ Az empirikus gyakorlatban találkoztam olyan keresleti függvénynyel is - a késóbbiekben is látni fogunk egyet -, amelynek a nulla árhoz tartozó relatív kereslete több mint 100\%.

\section{Felhasznált irodalom}

Bartus T. (2003): Logisztikus regressziós eredmények értelmezése. Az esélyhányados kudarcai és a marginális hatások. Statisztikai Szemle, 4., 25 p.

Berács J. - Rekettye G. - Piskóti I. - Lehota J. (szerk.) (2004): Marketingelmélet a gyakorlatban. KJK Kerszöv., Bp.

Chrzan, K. - Fellerman, R. (1997): A Comparison of Fulland Partial-Profile Best/Worst Conjoint Analysis. In Proceedings of the Sawtooth Software Conference, August, p. 59-69.

Cram, T. (2006): Smarter pricing: how to capture more value in your market. Pearson Education Limited, Harlow

Franses, P.H. - Paap, R. (2001): Quantitative models in marketing research. Cambridge University Press, Cambridge

Gabor, A. - Granger, C. W. J. (1964): Price sensitivity of the consumer. Journal of Advertising Research, 4, p. 40-44.

Gijsbrechts, E. (1993): Prices and Pricing Research in Consumer Marketing. Some Recent Developments. Intemational Journal of Research in Marketing, 10 (2), p. 115-151.

Gorman, M.F. (2005): Estimation of an implied price elasticity of demand through current pricing techniques. Applied Economics, 37, p. 1027-1035.
Greene, W. (2003): Econometric analysis. Fifth Edition, Prentice Hall, Upper Saddle River

Hague, N. (2004): The problem with price. White paper, B2B International

Hosmer, W.D. - Lemeshow, S. (2000): Applied Logistic Regression. New York

Hunyadi L. (2004): A logisztikus függvény és a logisztikus eloszlás. Statisztikai Szemle, p. 10-11.

Kézdi G. (2005): http://www.personal.ceu.hu/staff/ Gabor_Kezdi/Publications/Kezdi-2005-NobelKotetMcFadden.pdf

Kleinbaum, D.G. - Klein, M. (2002): Logistic regression. A self-learning text. Springer, New York

Kórösi G. - Mátyás L. - Székely I. (1990): Gyakorlati ökonometria. Közgazdasági és Jogi Könyvkiadó, Bp.

Kuhfeld, F.W. (2005): Marketing Research Methods in SAS. SAS Institute Inc., Cary N.C

Long, J.S. (1997): Regression Models for Categorical and Limited Dependent Variables. Sage, Thousand Oaks

Lyon, W.D. (2002): The price is right? Marketing Research, Winter, p. 8-13.

Martin, B. - Rayner, B. (2008): An Empirical Test of Pricing Techniques. Proceedings of the American Marketing Association Advanced Research Techniques Forum

Malhotra, N. - Simon J. (szerk.) (2009): Marketingkutatás. Akadémiai Kiadó, Budapest

Mcfadden, D. (1986): The choice theory to market research, Marketing Science, 5, p. 275-97.

Monroe, K. B. (1990): Pricing: Making Profitable Decisions. 2. edition. McGraw-Hill, Boston

Pauwels, K. - Fransens, P.H. - Srinivasan, S. (2003): Reference-based transitions in short-run price elasticity. University of Chicago, Chicago

Pritchard, M. (2009): Van Westendorp pricing (the Price Sensitivity Meter). http://www.5circles.com/wordpress/ blog/2009/05/van-westendorp-pricing-the-pricesensitivity-meter/mike-pritchard/

Rekettye G. (1999): Az ár a marketingben. Múszaki Könyvkiadó, Budapest

Székelyi M. - Barna I. (2002): Túlélókészlet az SPSS-hez. Typotex Kiadó, Budapest

Szúcs I. (szerk.) (2004): Alkalmazott statisztika. Agroinform Kiadó, Budapest

Wedel, M. - Leefland, P.S.H. (1998): A model for the effects of psychological pricing in Gabor - Granger price studies. Journal of Economic Psychology, (2), p. 237-260.

Weiner, J.L. - Zacharias, B. (2004): Pricing New-to-Market Technologies: An Evaluation of Applied Pricing Research Techniques. White paper, Ipsos Insight

Wertenbroch, K. - Skiera, B. (2002): Measuring Consumers' Willingness to Pay at the Point, Journal of Marketing Research, 39, p. 228-241.

Cikk beérkezett: 2010. 4. hó

Lektori vélemény alapján véglegesítve: 2010. 6. hó 